DENIS VIREN

State Institute for Art Studies,

Moscow
Images

vol. XXIV/no. 33

Poznań 2018

ISSN 1731-450X

\title{
Non-accidental presence.
}

The reception of Krzysztof Kieślowski in Russia

\begin{abstract}
Aвstract. Denis Viren, Non-accidental presence. The reception of Krzysztof Kieślowski in Russia. “Images" vol. XXIV, no. 33, Poznań 2018. Adam Mickiewicz University Press. Pp. 109-115. ISSN 1731-450X. DOI 10.14746/i.2018.33.09.

Krzysztof Kieślowski is a cult figure among Russian moviegoers, but "proving" this is not as easy as in the case of the popularity of other Polish classic names in Russia, such as Andrzej Wajda and Krzysztof Zanussi. Placing Kieślowski on the list of Polish filmmakers who have influenced Russian culture in this or some other way is a not obvious move. The article is an attempt at exposing the reader to the presence of the director's films in Russia through the history of the distribution of his films, an analysis of reviews by Russian authors and texts in which Kieślowski's name appears. It also discusses references to his films in works by other filmmakers. It is complemented by the statements of two Russian directors who talk about the importance of Kieślowski in their work and academic practice.
\end{abstract}

KEYwORDs: intercultural relations, Polish-Russian relations, film distribution, auteur film, foreign reception, Polish cinema abroad

A young married couple are lying in bed and watching a movie on a laptop.

He: I really can't watch it. It's nonsense.

She: Come on, Yegor, Kieślowski is a god.

He: He's a Pole, isn't he? I drove one Pole yesterday, such a bore.

She: Yegor, Kieślowski is not boring, he's just... subtle.

This dialogue comes from a romantic drama by the Russian director Oksana Bychkova Another Year (Eshche odin god, 2014). The film is about a crumbling marriage, which seems quite successful until at some point it becomes clear that the priorities of these two young people are very different. Although he has a university degree, Yegor has not found a job in his field, so he earns a living as a taxi driver. His wife has found a job in a modern office as a graphic designer and evidently has greater professional and life aspirations than her husband.

I think that the use of Kieślowski in the quoted scene (let us note that it has a private, almost intimate character) reflects well the status of this Polish director in the minds of Russian viewers. Theoretically, Wim Wenders, Jim Jarmusch, Kim Ki-duk or other favourite of arthouse cinema enthusiasts could have been used in his place. The director admitted in one interview how she was once impressed by 
The Double Life of Veronique (La double vie de Véronique, 1991)[1], but it is no longer that important to her. Kieślowski appears in her film as a symbol of auteur cinema, "not-for-everyone" cinema, which turns out to be another point of misunderstanding between the spouses.

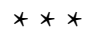

Writing about the reception of a filmmaker in a given country, and all the more about their potential influence on fellow artists, is not easy. I do not think it would be a gross exaggeration to say that Krzysztof Kieślowski is a cult figure among Russian filmgoers. But "proving" this is not as easy as in the case of the popularity of other Polish classic names in Russia, such as Andrzej Wajda and Krzysztof Zanussi.

In 2004, at the Festival of Archival Cinema in Gosfilmofond (National Film Archive), a discussion panel was held with the participation of Russian film experts and directors. Its subject was "The Cinema of Eastern Europe - Farewell to the Past", and it was devoted to the reception of the cinema of former socialist countries in the new socio-economic conditions. In a published transcript with the characteristic title "No one will ever make Ashes and Diamonds, nor Silence and Cry anymore", Kieślowski's name does not appear at all.[2] Why? Perhaps it is because, firstly, his place on the list of Polish filmmakers who influenced Russian culture is not so obvious, and secondly, those who took part in the panel were representatives of an older generation.

"The Polish Film School" was one of the most important cultural phenomena for several generations of Soviet filmmakers and "ordinary viewers". It was to a large extent a reference point, "a window on Europe" - just like Poland in general. It is not surprising that it was in the Soviet Union that the first book about Andrzej Wajda, written by Miron Chernenko, was published, a point always emphasised by the filmmaker who made The Sewer (Kanat, 1957).[3] But these were different times. Despite the fact that in the 1960s and 1970s the distribution of Polish films (those that were really outstanding and significant) was very limited, quite a lot of them were successfully "smuggled". Alongside the intensification of the opposition movement in Communist Poland, the "window on Europe" was slowly shutting.

Against this backdrop, the fate of Kieślowski's films in Russia turns out to be quite confusing. The works by the Polish director "started to exist" in the USSR early when in 1979 Camera Buff (Amator, 1979) was awarded the main prize at the Moscow Film Festival. This was quite a paradox, considering that the film was a shining example of "the

[1] "Rezhyssior Oksana Bychkova: 'Ljudi na ulitsah tak pogruzheni v sebya, shto kameru mozhno ne priatat"', https://iz.ru/news/339862 (accessed: January o8, 2018).
[2] “... Nikto bolshe ne sdelayet ni Piepiel i almaz, ni Tishinu i krik", [in:] "Kinovedcheskie Zapiski” 2005, no. 71, pp. 35-51.

[3] A. Wajda, "Słowo wstępne", [in:] M. Czernienko, Bliska zagranica. Szkice filmowe o Polakach i dla Polaków, Warszawa 2007, p. 7. 
cinema of moral anxiety", whose spiritual leader Andrzej Wajda was then - after Man of Marble (Człowiek $z$ marmuru, 1981) - already on the black list in the Soviet Union. On the other hand, this award can be treated as further testimony that from the very beginning Kieślowski was primarily interested in man, in spiritual and non-political matters, so his social criticism may have even been "not noticed". It is true that Chernenko wrote that Camera Buff (Amator) "was in the cinemas purely conventionally so that the formalities would be completed" [4], but the fact is important! [5]

Obviously, Kieślowski's films from the 1980 os could not get into Soviet distribution, so the wave of true popularity for the director of Blind Chance (Przypadek, 1981, prem. 1987) occurred in the 1990s, the era of VHS cassettes, but mainly concerned his French films, starting with The Double Life of Veronique, as well as The Decalogue (Deka$\log , 1988 / 89$ ). The Polish period of feature films (not even mentioning his documentaries) remained in the shadow of Three Colours (Trois couleurs, 1993/94) for a long time. From the perspective of the film historian this seems unfair, because there is no doubt that Kieślowski created his greatest works in Poland, while in France he tried only to transfer his poetics and issues to foreign soil, to universalise his achievements. The Russian critics who wrote about the trilogy emphasised the opposition between The Decalogue, which was modest in terms of visual means and complex in terms of content, and Three Colours, calling it "continental cinema". [6] Judgments about the director's latest films were rather restrained, especially against the backdrop of the opinions on The Decalogue, but still positive. It was emphasised that he combined in his films "surgical" and "disciplined" direction with sensitivity; the master gained the title of "the film leader of a united Europe" [7] and even of "neoclassic".

Kieślowski managed to "work out" a certain model of auteur film in the 1990s. Working in France, he became - it can be said - a model creator of arthouse cinema, as evidenced by the awards he received at the biggest European film festivals (though his last film's loss in Cannes to Pulp Fiction [dir. Q. Tarantino, 1994] heralded a fatigue with this poetics and a "change in priorities" in cinema). In his trilogy, the author of Blind Chance masterfully combined familiar, commonly known realities and universal problems with a metaphysical worldview and visual finesse. In Russia of the 1990s, the last two things were definitely absent on the screen (and to a large extent in the surrounding reality), because cinema had assimilated American patterns, just as in the rest

[4] M. Czernienko, "Krótki kurs historii kina polskiego na ekranach radzieckich", [in:] idem, Bliska zagranica, op. cit., p. 74.

[5] In 1963, the jury of the Internatinal Film Festival in Moscow, chaired by Grigoriy Chukhray, awarded Grand-Prix to the film Eight and a Half $\left(81 \frac{1}{2}, 1963\right)$. Fellini's masterpiece did not get into Soviet distri- bution (contrary to the regulations), which caused a major scandal.

[6] Z. Abdullaeva, "Kontinentalnoye kino", [in:] "Iskusstvo kino" 1995, no. 2, pp. 15-17. [7] P. Shepotinnik, "Zhydkiye kristally", [in:] "Iskusstvo kino" 1994, no. 6, p. 72. 
of the former Eastern Bloc. Kieślowski's late cinema satiated the desire for a new, aestheticized spirituality and turned out to be close to the next generations of viewers, those who did not necessarily know Wajda or Kawalerowicz. It is not accidental that in the film mentioned at the beginning, Another Year, the married couple are watching A Short Film About Killing (Krótki film o zabijaniu, 1987, prem. 1988] - the characters are discussing the "yellow filters", and at some point, during a drastic scene, the girl turns away from the screen because "she can't look at it".

In an article entitled "Cinema and life finished at the same time", the critic Sergei Dobrotvorsky concluded: "After his death, the fashionable question 'will cinema have a second century' has become rhetorical for me. Not because with the death of the Polish director films will stop being made, but because cinema, so rapidly losing its magic, has lost one of its most mysterious creators - a mathematician, a magician and a moralist".[8]

Three years after the untimely death of the director, Andrei Plakhov, one of the leading Russian film critics wrote:

Kieślowski was one of the last authors of cinema who treated it not as an attraction or fun but as a moral message. He defeated the cultural barrier between East and West, between Europe and America, between classic and contemporary cinema. He forced the people of the late twentieth century to listen to themselves. He was in such a hurry because he knew: today they can still hear him. Will they hear tomorrow? (...) Bergman, we would have written not long ago, has only one rival in world cinema - Krzysztof Kieślowski. Now we have to write: he had.[9]

He was followed by a young critic analysing Run Lola Run, and on the occasion paying tribute to the Polish director: "He achieved psychological and visual perfection in dealing with indefinite, confusing materials devoid of carnal shape. (...) with the death of Kieślowski, the existential psychologism of artistic images and painterly symbols came to an end".[10]

In recent years, the interest in Kieślowski in Russia has not diminished, but vice versa - it has deepened. The cinema historian Oleg Kovalev, in a relatively recent comprehensive article, called Kieślowski "perhaps the last great director of the past century".[11] The popularity of the Polish filmmaker is confirmed by facts. Regular festivals of his works are held (the last one took place in one of the main Moscow cinemas "Oktiabr" last June [2018]); in 2010, the autobiography About Myself (O sobie) was finally published in Russian, and a year later Dramaturgy

[8] S. Dobrotvorsky, Kino na oshtchup', Sankt-Petersburg 2005, p. 334.

[9] A. Plakhov, Vsego 33. Zviozdy mirovoy

kinorezhissuri, Winnica 1999, pp. 151, 153.
[10] I. Sukmanov, "Dogonayte Lolu", "Iskusstvo kino" 200o, no. 6, p. 28.

[11] O. Kovalov, Krzysztof Kieślowski. Posledniy iz velikih, http://www.cinematheque.ru/threadtree/16007 (accessed: January 08, 2018). 
of Reality (Dramaturgia rzeczywistości) was translated - a short, but very succinct master's thesis (the scenario of The Decalogue was published in translation by the outstanding translator Ksenia Staroselskaya in the 199os); and students of film studies are also eager to write about the director's works.

Kieślowski's films leave ample room for interpretation; one can look at them from various points of view. The Russian humanities have at least a few interesting proposals in this respect. For example, for the outstanding Polish philologist and translator Irina Adelgeim, the films of her favourite Polish director became a pretext for reflections on the problems of the relationship between the word and the image, and of means of communication in the modern world.[12] Film researcher Irina Tatarova, in turn, offers an analysis of Polish cinema, including that of Kieślowski, from the position of Russian philosophical and religious thought.[13] It is worth noting that her book is enhanced by appendices, where we find, among other things, an extremely valuable list of publications on Kieślowski in Russian.[14] These are mainly reviews written on a regular basis, and their number is impressive - 72 items! - of which about a half relate to the "French" period of the director's work.

Oleg Dorman, a documentary filmmaker, lecturer and the translator[15] who translated the transcript of the workshops for directors and actors taught by Kieślowski in 1994 in Amsterdam, when asked about the director's place in his life, said: "The presence and importance of Kieślowski is for me a deeply private thing. I think that this is the highest thing the author and the viewer can only dream about". Let me quote the rest of the statement:

His films are among the greatest achievements of film art and the best events in my life. He is the last author who made films "for me": since Kieślowski departed, I have not been waiting for anyone's new films. Quite opposite, every year I watch his works again with film school students. And although Fellini, Bergman and Chaplin fortunately affect younger people more strongly, I have the impression that it is the meeting with Kieślowski that has for many years proved to be the main experience for many of them in the entire syllabus of film history. Probably not only because he is closer in time; he is closer in terms of the situation in which he worked - I have often wondered that becoming Fellini in Italy or Bergman in Sweden is easier than becoming Kieślowski in socialist Poland. But it is not everything. If

[12] I. Adelgeim, Przeczucie słowa (notatki rosyjskiego filologa o polskim reżyserze), "Kwartalnik Filmowy" 1998, no. 24, pp. 126-132. Let us add that Adelgeim translated the book About Myself (O sobie) into Russian.

[13] I. Tatarowa, Ergo Sum. Poszukiwania sensu istnienia w polskim i radzieckim filmie 1960-199o, Warszawa 2004.
[14] Thank you to Mikołaj Jazdon for showing me this source.

[15] Dorman's most famous documentary is Word for word (Podstrochnyk, 2009). On its basis, a book with the same title was written, which in 2012 was published in Polish (Lilianna Eungina. Stowo w stowo, trans. K. Romanowska, Warszawa 2012). 
there is a development of the film language, as in science there is a "front edge" which does not diminish the achievements of the past, Kieślowski's cinema is that front edge. After him, one must not work worse. He did in dramaturgy as much as Einstein did in physics, though it does not seem as radical. And one more thing - personal charm. I did not have the opportunity to meet Kieślowski, but he seems to me the best man among all the masters of the film that I know. His path is for me a model of honesty and dignity.[16]

Such a deep, emotional reception of Kieślowski by a Russian filmmaker and lecturer could not be left unnoticed. When in 2005 the project "Russia-Poland. New Gaze" involving an exchange of Polish and Russian film school students, one of the participants was Irina Volkova - then a student of the Advanced Course for Screenwriters and Film Directors in Moscow (where, among others, Dorman worked as a lecturer together with director Vladimir Fienchenko, a great propagator of Polish cinema among students and also a film translator).

The short documentary filmed by Volkova stands out from the others, at least because it is an interview with a usual and unusual person at the same time - Krzysztof Kieślowski's daughter. It is impossible not to mention the fact that the director from Russia was the first one to be given an interview by Kieślowski's daughter, which made her film very important also for Poland. Irina Volkova describes her relations with the works of the author of Camera Buff as follows:

Kieślowski appeared in my life in the form of a page from a story about himself abandoned by someone at a bus stop. Later there were Blind Chance, The Double Life of Veronique and Three Colours. Everything about the things familiar to me, about what I like and think is most important in cinema and in life - about man and his feelings, about time and the interpersonal relations that connect everyone, different people into one, great man.

The jigsaw pieces finally worked out when I was invited to the project "Russia-Poland. New Gaze", where I worked on a documentary about Krzysztof with a team of professionals and well-known lecturers from the Katowice Film School. It was an amazing experience - to meet his close friends, to hold a big, touching interview with his daughter Marta. At that time I got to know him better as a man and as a director. At all stages of the work I had the impression that he was somewhere nearby. Each time I had doubts, I felt his support.

It is amazing that in fact Poles turned out to be the same as in Kieślowski's films: affectionate, courageous and contemplative - in art I am interested in examining these human features. But most importantly, what Kieślowski gave me - three close friends living in Warsaw.[17]

It seems that the then-freshman director managed to transfer these feelings to her film My Kieślowski (2005) - the title itself emphasises her personal attitude towards the subject. In addition to Kieślowski's daughter's tale about her father, in the film we can see a report from the auditions for the remake of Blind Chance, which - according to the concept of the overall project - presents a certain cross-section of 
Polish society seen through the eyes of a foreigner, and, on the other hand, it proves the topicality of this film masterpiece in completely different conditions than the times of its creation.

The figure of Krzysztof Kieślowski, as one can see, is present in Russian film culture at various levels - in education, in documentary films, in references to his works in feature films, as well as in film studies publications, critics' texts and cinema enthusiasts' awareness. Respect for Kieślowski is declared by many directors, for example, Andrei Zvyagintsev or Vladimir Kott. Perhaps Kieślowski's presence in Russia is not as explicit as the influence of Polish directors of the older generation, but the author of The Decalogue is undoubtedly for us one of the important landmarks on the world film map.

“...Nikto bolshe ne sdelayet ni Piepiel i almaz, ni Tishinu i krik”, [in:] "Kinovedcheskie Zapiski” 2005, no. 71

Abdullaeva Z., "Kontinentalnoye kino”, [in:] "Iskusstvo kino” 1995, no. 2

Adelgeim I., „Przeczucie słowa (notatki rosyjskiego filologa o polskim reżyserze)”, "Kwartalnik Filmowy" 1998, no. 24

Czernienko M., Krótki kurs historii kina polskiego na ekranach radzieckich, [in:] idem, Bliska zagranica. Szkice filmowe o Polakach i dla Polaków, ed. T. Lubelski, Warszawa 2007

Dobrotvorsky S., Kino na oshtchup', Sankt-Petersburg 2005

Kovalov O., Krzysztof Kieślowski. Posledniy iz velikih, “Sinemateka”, 27.06.2011, http://www.cinematheque.ru/threadtree/16007

Plakhov A., Vsego 33. Zviozdy mirovoy kinorezhissuri, Winnica 1999

„Rezhyssior Oksana Bychkova: »Ljudi na ulitsah tak pogruzheni v sebya, shto kameru mozhno ne priatat «", "Izviestija”, 19.08.2008, https://iz.ru/news/339862

Sukmanov I., Dogonayte Lolu, "Iskusstvo kino" 2000, no. 6

Shepotinnik P., "Zhydkiye kristally”, [in:] "Iskusstvo kino” 1994, no. 6

Tatarowa I., Ergo Sum. Poszukiwania sensu istnienia $w$ polskim i radzieckim filmie 1960-1990, Warszawa 2004

Wajda A., "Słowo wstępne”, [in:] M. Czernienko, Bliska zagranica. Szkice filmowe o Polakach i dla Polaków, ed. Tadeusz Lubelski, Warszawa 2007 